This is an electronic reprint of the original article. This reprint may differ from the original in pagination and typographic detail.

Author(s): Vos, Marita; Westerhoudt, Evelyn

Title: $\quad$ Trends in government communication in The Netherlands

Year: $\quad 2008$

Version:

Please cite the original version:

Vos, M., \& Westerhoudt, E. (2008). Trends in government communication in The Netherlands. Journal of Communication Management, 12(1), 18-29.

https://doi.org/10.1108/13632540810854217

All material supplied via JYX is protected by copyright and other intellectual property rights, and duplication or sale of all or part of any of the repository collections is not permitted, except that material may be duplicated by you for your research use or educational purposes in electronic or print form. You must obtain permission for any other use. Electronic or print copies may not be offered, whether for sale or otherwise to anyone who is not an authorised user. 
Vos, M. \& Westerhoudt, E. (2008), 'Trends in government communication in The Netherlands'. Journal of Communication Management, Volume 12, Issue 1, pp. 18-29.

\title{
Trends in Government Communication in the Netherlands
}

\author{
Marita Vos and Evelyn Westerhoudt \\ Government Communication Research Group, Utrecht University of Professional Education, the \\ Netherlands
}

\begin{abstract}
Purpose - To provide a current state of the art of government communication in The Netherlands which can help to promote a dialogue about how communication quality in this field can be improved further.

Design/methodology - In 2006 a survey was conducted for the second time to trace the communication trends in ministries, provinces, municipalities and water boards. The survey was set up in association with sector representatives and it is implemented every two years. The respondents were the top manager and the communication managers of all organizations in the 4 public sectors. The questionnaire was answered online and the response was 33\%.
\end{abstract}

Findings - The communication budget remained reasonably intact, even in more difficult years, and is now regarded with cautious optimism. The principal goals of government communication are to make government action more transparent and to generate interaction with the outside world. The respondents saw the main tasks as: communicate from a wider societal perspective, make the organization more communicative internally and (especially in the municipalities) do more work on citizen participation. What strengths should a communication professional possess? As in 2004, when a similar survey was conducted, the most frequently cited competencies were analytical insight and empathy. In the disciplinespecific competencies, advisory skills and knowledge of the target group were mentioned most often. Knowledge of the political environment scored slightly lower than in 2004.

The section on the main developments in government communication met with a mixed response. The ministries said more unity and coordination. The provinces mentioned, amongst others, a shift from a reactive to pro-active approach. The municipalities stressed citizen participation and the water boards stressed staying closer to people and their living environment. As in 2004, a common denominator for all the sectors was more attention to digital communication.

Now that government communication has further developed, coherence and differences in approach between the tiers of government have to be taken into account.

Practical implementations - The survey provides insight into what the various public sectors (ministries, provinces, municipalities and water boards) see as the added value of communication.

Originality/value - This investigation focuses on government communication and gives insight into this area of communication.

Paper type - Research paper

Keywords - Government communication, competences and developments; ministries, provinces, municipalities and water boards. 
Vos, M. \& Westerhoudt, E. (2008), 'Trends in government communication in The Netherlands'. Journal of Communication Management, Volume 12, Issue 1, pp. 18-29.

\section{Introduction}

In 2006 the Government Communication group at Utrecht University of Professional Education collected core data on how Government Communication was being implemented for a second time. The research was agreed jointly with representatives from all public sectors. The views of the director/head of communication and the top manager of all ministries, provinces, municipalities and water board were recorded. All 1074 persons in the target groups were approached (Vos \& Westerhoudt, 2006).

The first survey on government communication trends was undertaken in 2004. The Research Group Government Communication was created and in discussion with representatives in government communication it was decided that survey research was needed to monitor progress in government communication. The representatives assumed that government communication was quite well developed in the Netherlands and they were interested to see how communication quality could be further improved. In 2004 directors/heads of communication and top managers were questioned along with the top political managers (Middel, 2004; Vos, 2006). In 2006 it was decided that the top political managers would be questioned less frequently than people in other positions as they had more problems freeing up time to fill in surveys (ministers, Queen's Commissioners, mayors, chairs of the water boards). It was concluded that the response would probably be higher if the questions were asked less often.

All the questions were put to communication staff (directors/heads of communication) and a selection were put to top managers (i.e. secretaries/secretaries-general as the most senior officials who lead the staff of civil servants in their organization). This report compares the answers for 2006 with the answers for 2004. The differences are highlighted by splitting some of the results into different government sectors: ministries, provinces, municipalities and water boards.

To provide context, background information about the government in the Netherlands is provided. Then we will explain the research methodology and present the findings. Areas for questioning are the communication budget, communication staff numbers, government communication goals and the main challenge as seen by the respondents. Then we will present findings about the general competencies of communication professionals and the senior communication advisor, developments in the discipline and the current state of affairs. This is followed by a discussion.

\section{Background information about the government in the Netherlands}

In the Netherlands government comprises over 1,600 organisations and bodies, including 13 ministries, 12 provincial authorities, 27 water boards and 443 municipal authorities. The latter bodies are directly elected and were the subjects of the research. The Dutch government also includes autonomous administrative authorities, such as police regions and chambers of commerce, and public bodies for industry and the professions; these organizations were not part of the research. In the Netherlands many utilities and other organisations that one might assume form part of government are nowadays in private hands. They include for example, health insurance funds, boards of private schools and benefit agencies. These were also not part of the research.

The Netherlands has three tiers of government: central, provincial and municipal. In central government there are ministries (central government departments), staffed by civil servants who prepare and deliver government policy. The Government Information Services (RVD) plays a central role in the communication activities relating to general government policy (Katus \&Volmer, 2000).

The Netherlands is divided into provinces. They have responsibility for: land-use planning, transport, the economy, agriculture, environmental management, recreation, wildlife and countryside, social work, 
culture and local government organization. They also oversee the work of the water boards and the financial affairs of the municipalities.

Water boards are established and dissolved by provincial ordinance. They are responsible for flood defences and water management and they take on tasks such as managing and maintaining dykes and pumping stations. Many water boards are responsible not just for water levels, but also for water quality and purification.

Municipalities form the lowest tier of government in the Netherlands, after central government and the provinces. They apply national legislation on matters like social security. They provide for the construction of new residential areas and control development in existing urban areas and in the countryside. The municipalities are also responsible for the roads and other areas such as education (see http://www.overheid.nl/english/aboutgov/).

\section{The research methodology}

In 2004 the survey on government communication was conducted partly on paper and partly online. In 2006 the questions were asked entirely online. The response was $33 \%$ as opposed to $43 \%$ in 2004 . We assume that this reduced response is partly due to the digital format. Some respondents failed to complete the whole questionnaire. Others said it was too long and a few gave up towards the end when asked for demographic details.

All the directors/heads of communication and the top managers were invited to participate, so there was no random sampling. The response from the different sectors was as follows (see Table 1):

Table 1: Response according to position, expressed in numbers and percentages

\begin{tabular}{|c|c|c|c|}
\hline Position & $\begin{array}{l}\text { Popu- } \\
\text { lation }\end{array}$ & Response & $\begin{array}{l}\text { Response } \\
\text { percentage }\end{array}$ \\
\hline Secretaries-general & 13 & 4 & $31 \%$ \\
\hline $\begin{array}{l}\text { Dir. Communication } \\
\text { Ministries }\end{array}$ & 13 & 8 & $62 \%$ \\
\hline Provincial secretaries & 12 & 7 & $58 \%$ \\
\hline $\begin{array}{l}\text { Heads of } \\
\text { Communication, } \\
\text { Provinces }\end{array}$ & 12 & 5 & $42 \%$ \\
\hline Municipal secretaries & 485 & 109 & $22 \%$ \\
\hline $\begin{array}{l}\text { Heads of } \\
\text { Communication, } \\
\text { Municipalities }\end{array}$ & 485 & 192 & $40 \%$ \\
\hline $\begin{array}{l}\text { Secretaries, } \\
\text { Water Boards }\end{array}$ & 27 & 9 & $33 \%$ \\
\hline $\begin{array}{l}\text { Heads of } \\
\text { Communication, } \\
\text { Water Boards }\end{array}$ & 27 & 17 & $63 \%$ \\
\hline Total & 1074 & 351 & $33 \%$ \\
\hline
\end{tabular}


The average response was higher for communication staff than for top managers. The response from top managers was relatively low in the municipalities. Because municipalities strongly outnumbered the other organizations the average response rate was suppressed, however, this lower response rate has little effect on the reliability of the data. Where there were notable differences between the groups this is commented in the research findings.

In $2006,54 \%$ of the respondents in the communication group were female and $46 \%$ were male. Women now seem to be slightly outnumbering men in key communication jobs. This was true in most of the sectors, but the split was lower in the ministries.

The ages were widely spread in the communication group, though there were relatively few respondents aged 55 and over. Around half of these had completed a communication programme at a university or college of higher education. The others had followed different programmes of study in higher education.

\section{The communication budget}

In 2004 we asked the respondents if the communication budget (not including the staff numbers) had shrunk, stayed the same, or grown compared with the previous year. We also asked them for a prognosis for 2006.

On average, the communication budget had grown slightly in all sectors. Although it is not clear in the investigation results per se, the increase reported seems a little more than inflation, and might have been spent on staff (see the next question). A slight increase was, on average, also predicted for 2006 (see Figure 1).

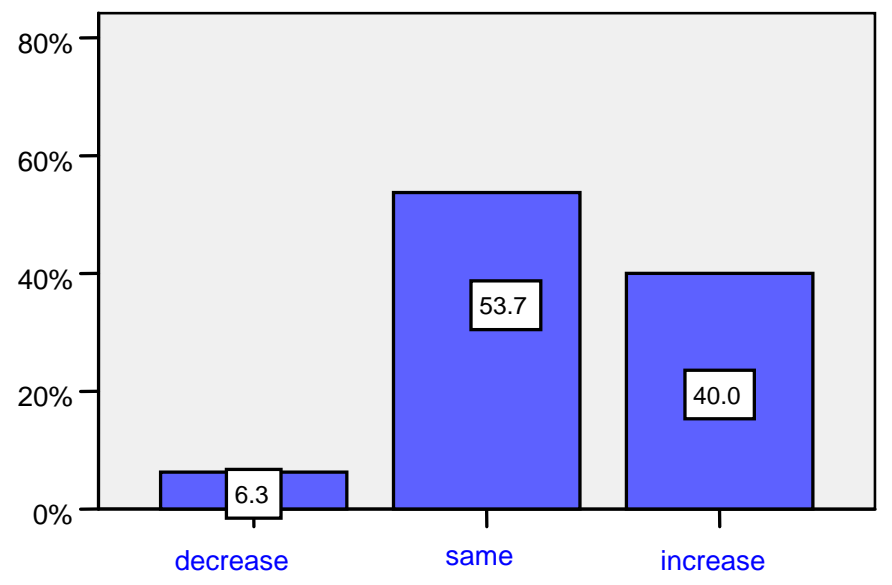

Figure 1. Communication budget prognosis (excluding staff)

The figure shows the answers from both the top managers and the communication group. There was little difference between the two. The expectations in the ministries were somewhat less positive than in the other sectors.

In the previous survey the majority of the respondents said that the budget had remained the same in 2003 , though there were relatively frequent reports from the ministries that it had shrunk. The prognosis for 2004 was largely that the budget would remain the same. 
It seems therefore that in 2003 and 2004 there was a stable or slightly downward trend, a stable or slightly upward trend has become visible in 2006.

\section{Communication staff numbers}

We asked the respondents in the communication group if the staff numbers had declined, stayed the same, or risen in 2005 compared with the previous year. We also asked them for a prognosis for 2006. In 2005 the communication staff numbers declined slightly in the ministries, remained around the same in the provinces and municipalities, and increased slightly at the water boards. Most of the respondents predicted that the numbers would stay the same for 2006 although more people anticipated an increase than a decline. This prediction was given by all sectors (see Figure 2).

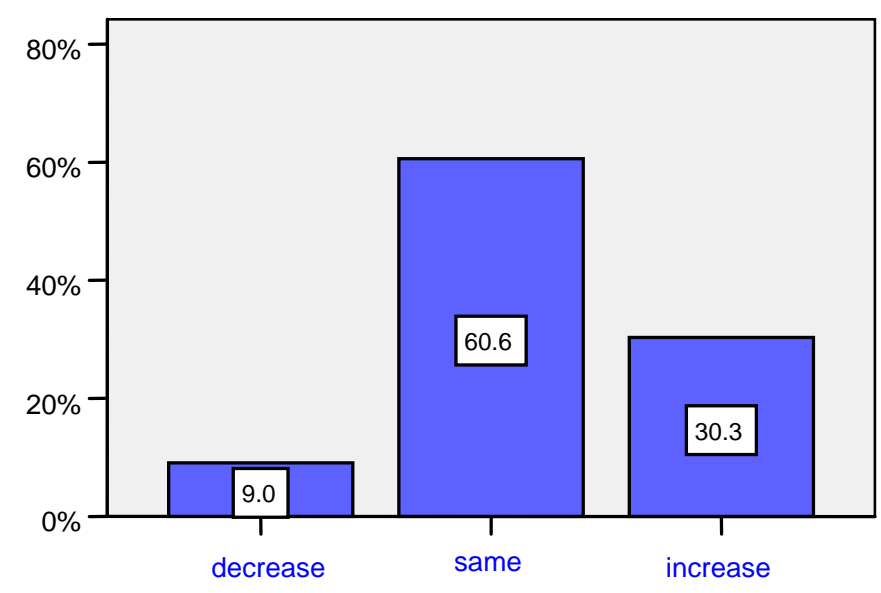

Figure 2. Increase in staff numbers prognosis

In the first survey most people reported that staff numbers had stayed the same for 2003. A somewhat smaller number reported a rise and a very few reported a decline. On average, the prognosis for 2004 was that staff numbers would stay the same or increase slightly.

It seems therefore that caution prevailed in 2005 , with a decline in staff numbers at the ministries (not only communication staff) and only tentative positive expectations for 2006.

\section{Government communication goals}

We asked both groups (top managers and communication managers) to rank four government communication goals in order of importance. They could also add any other goals that they considered important. On average, the highest scores went to transparency on government policy (especially in the ministries) and interaction with the outside world (in the other sectors). The ranking was as follows:

1. Interaction with the outside world

2. Transparent government policy

3. A policy support base

4. A positive image 
The ranking was the same for both groups. These results correspond more or less with the results of the 2004 survey, except for the fact that, in 2004, a policy support base came top in the water boards. This too has been replaced by interaction with the outside world. It appears that in 2006 a policy support base and a positive image ranked lower as goals, or they may have been less socially desirable as an answer.

The respondents also added some goals to the list.

Amongst which were:

Enhance trust in the government;

Manage expectations;

Keep the public informed so that people can participate in our democracy;

Realize a vibrant (local) democracy;

Make government action understandable to various target groups;

Internal communication to realize integrated communication;

Monitor developments among public groups;

More accountability.

We might conclude that there is a greater emphasis on interaction, monitoring public perception, legitimacy and trust.

\section{The main challenge}

We asked communication group to explain what they saw as the main communication challenges for their own organization in 2006 . The answers were mixed, but below are the most frequent answers for each sector.

\section{Ministries}

A further shift from a reactive to a pro-active approach;

Communication from a broader societal perspective rather than separate policy domains;

More coordination in advice now that this is realised in press information;

Better targeted communication and more selective topics.

Provinces

Working on a more visible presence;

Improving internal communication in the organization;

Demonstrating the added value of the province.

Municipalities

Working on citizen participation;

More attention to digital communication;

Clearer communication.

Water boards

A stronger external focus;

Increasing public awareness;

More citizen and stakeholder involvement; 
More theme-based project communication.

In the first survey (2004) two clusters of comments finished with high scores, particularly in the municipalities. The first was More citizen and stakeholder involvement, which covered comments on the promotion of participation, transparency, better information services and a stronger relationship between the citizen and the government. The second cluster concerned digital communication, which covered comments on e-government, developing the Internet site and intranet, electronic transactions and customer relations. A similar picture emerged for municipalities in 2006 , with differences in emphasis for each of the sectors.

For central government level we see a need for cooperation, at the intermediate level of the provinces visibility is stressed, while municipalities and water boards primarily mention participation and involvement. Digital communication also remains a challenge for government organizations on all levels.

\section{General competencies of the communication professional}

We asked the respondents in both groups (top managers and communication managers) to name the three overall competencies that they considered most important in communication professionals.

Analytical insight, cont skills and an overall perspective (helicopter view) scored high. Empathy, a network focus, creativity and listening skills were also frequently cited. These results match the results of the last survey in 2004.

Some respondents added competencies to the ten provided in the list, namely: persuasiveness, and an affinity with the political and societal environment.

At the ministries empathy scored highest, followed by creativity and listening skills. In the provinces analytical insight came top, followed by network focus and empathy. In the municipalities and water boards analytical insight and contactual skills tied for top place.

An overview by group, top managers versus communication managers, is presented below to show differences in perceptions about the required competencies (see Figures 3 and 4). It is important to note that the municipalities dominated the calculations for the group averages. The scores for contactual skills and analytical insight were high in both groups. Top managers gave a higher score for empathy than communication staff. Interestingly, when the same question was presented to top political managers in 2004, empathy was also considered more important than advisory skills. Perhaps they associate advisory skills with an ability to argue persuasively, whereas what matters to them is the ability to understand what goes on in management and policymaking positions. There may also be differences in what people understand by the competencies in the list. But it seems that, within the general competencies, the quality of dialogue between communication experts and policymakers is seen to be important. 


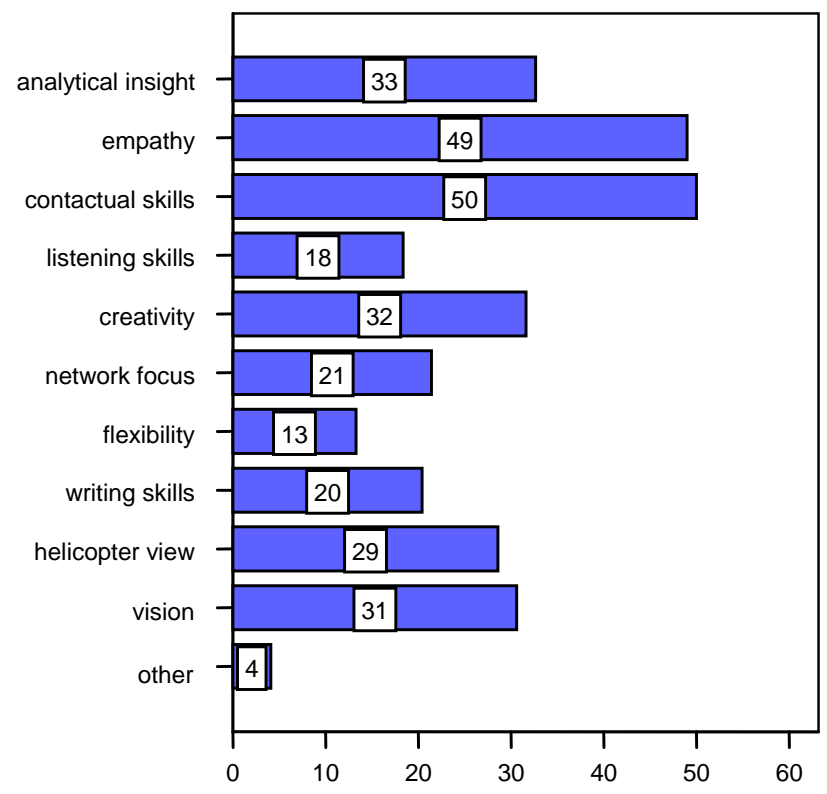

Figure 3. Top managers: general competencies for communication professionals, expressed in percentages

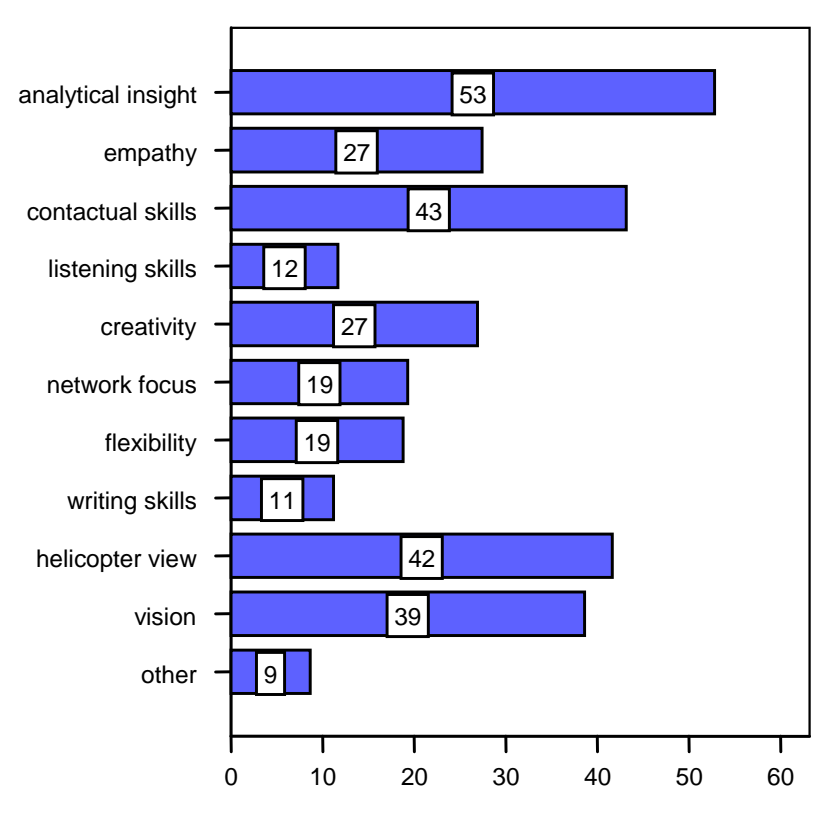

Figure 4. Communication managers: general competencies for communication professionals, expressed in percentages

\section{The senior communication advisor}

We asked the respondents in both groups to name the skills they considered most important for a senior communication advisor. The conclusions correspond largely with those of the previous survey. The two groups were in agreement.

Advisory skills and knowledge of the target group scored high in all sectors (see Figure 5). Knowledge of the political environment was also considered important, albeit less so in the water boards. Knowledge of the media scored high, though slightly lower in the ministries, where media relations is often undertaken by media specialists. 


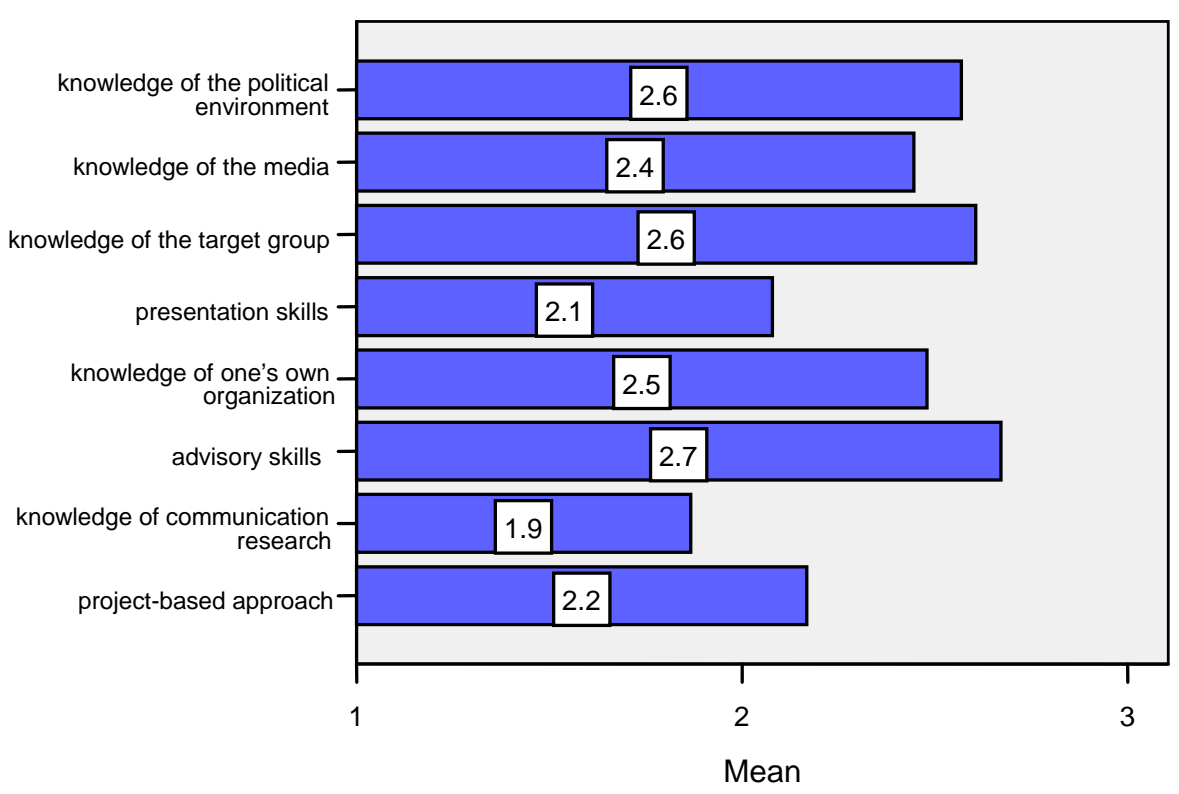

Figure 5. Most important skills for a senior communication advisor, expressed in means

Advisory skills and knowledge of the target group are deemed most important.

\section{Developments in the discipline}

We invited the communication group to name the most important developments in government communication in 2006. The most frequent answers are listed below for each sector.

\section{Ministries}

More unity and coordination, both interdepartmental and with executive organizations;

Further professionalization by e.g. media- and influence-analyses;

More attention to communication to support the primary process.

\section{Provinces}

A shift from a reactive to a pro-active approach;

Accessibility via digital communication;

From communication to policy advisor.

\section{Municipalities}

Less information and more bridges;

Digital communication and e-services;

Interactivity and citizen participation;

Municipal councils willing to communicate more actively. 


\section{Water boards}

Staying closer to the people and the living environment;

Digital services;

Transparency and support base.

In the first study (2004) the most frequently named developments - especially in the municipalities - were: digital communication, interactive policy-development, transparency, and the relationship between the government and the citizen. Though the phrase 'interactive policy-development' occurred less often in 2006, people did speak of 'interaction' or 'citizen participation'.

The picture differs for each sector and there is a similarity with the main challenge reported in question 6 . Ministries mention coordination of communication, provinces visibility, and municipalities and water boards participation or involvement.

\section{Current state of affairs}

We presented the respondents in each group with a set of statements and asked them to express a level of agreement in each case.

One strongly endorsed statement was: We immediately correct misreported facts in the media. Another was: Risk and crisis communication get our full attention. This indicates a high level of attention to media relations and crisis communication. Media relations has always been relatively well developed in government organizations in the Netherlands. However, attention on crisis communication has increased after some crises occurred in recent years, e.g. an explosion at a fireworks factory in Enschede in 2000 and a fire in a café-bar in Volendam in 2001, that both caused many casualties among civilans.

One statement that received very little endorsement (but more than in 2004) was: All our documents that fall under the Public Information Act can be found on our Internet site. The least endorsed statement was: Research forms an integral part of each important communication activity in our organization, although, this statement was endorsed more often in ministries than in other sectors, e.g. the municipalities. 
The results are shown in a line graph with a line for each group (see Figure 6). The differences between the groups are slight.

$$
\text { entirely disagree disagree neutral agree entirely agree }
$$

Policy development takes place interactively in our organization.

We immediately correct misreported facts in the media.

We respond $24 / 7$ to the information needs of journalists

Our policy managers have a good idea of the added value the communication discipline has to offer.

Our political managers have a good idea of the added value the communication discipline has to offer.

The communication department has ensured that internally people know what communication has to offer.

All the external output from our organization is comprehensible to the target group.

Advice is more important than implementation as a communication task.

All our documents that fall under the Public Information Act can be found on our Internet site.

We make extra efforts to reach target groups which are hard to penetrate (e.g. the elderly and immigrants).

Research is an integral part of each important communication activity in our organization

Communication has gained a full and proper place at the heart of policy.

We pay full attention to risk and crisis communication.

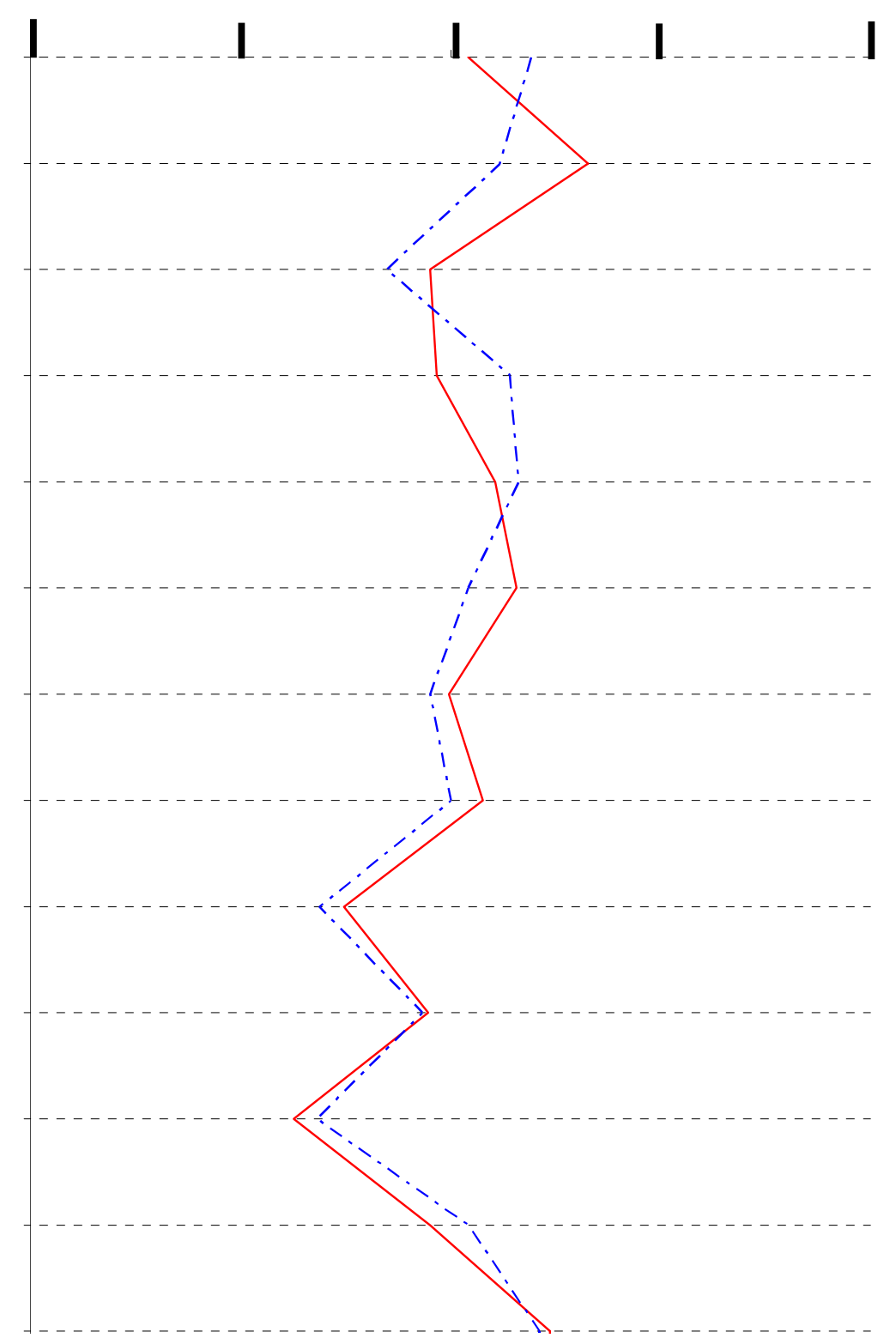

Figure 6: All split according to occupational group: answers to statements, expressed in averages. The lines unite the answers per sector. 


\section{Discussion}

Many of the results invite further discussion. Specifically, there are some interesting differences between the sectors, differences in vision between the occupational groups (top managers and communication managers), and some contradictions in the answers.

\section{Differences between the sectors}

The results of the 2006 survey are split according to sector. There are noticeable differences in the priorities accorded to government communication goals and the main challenges. The various tiers of government have their own focus and can complement one another in their communication with the public.

In the open question on the main communication challenge the ministries mentioned, amongst others, communication about societal issues rather than separate policy domains. The provinces and water boards emphasized more visibility for the organization, while the municipalities often accorded citizen participation as most important.

There were also similarities. For example, in all sectors, digital communication was frequently mentioned as an important issue and as a development in the discipline. The next survey will explore this topic further.

\section{Differences between top managers and communication experts}

The results often corresponded for both groups, but there were differences in vision. This was particularly noticeable in the general competencies required of communication professionals. The top managers found contact skills and empathy more important that analytical insight, while the communication managers found the opposite. A dialogue would probably shed more light on the background to these differences. Perhaps the concepts triggered different associations for the two groups. Does a communication professional get closer to policy and management by developing empathy or does empathy with a policy environment entail more of a helicopter view and an analytical approach to the influences at play? The quality of the dialogue between communication advisors and top political managers was deemed important.

\section{Contradictions in the answers}

A comparison of the results also raises some discussion points. For instance, why is so little importance attached to writing skills? Some responses to statements suggested that some of the external output from government organizations is not understandable to the target groups, while others underlined the importance of transparent government policy.

Another example of an apparent contradiction is the low importance attached to knowledge of communication research despite the high score for knowledge of the target group - which, after all, has to come from somewhere. Possibly the respondents were thinking only of formal research via surveys etc. and not of monitoring systems. Knowledge of the target groups calls for research.

\section{Conclusions for the profession and higher education}

Nowadays the main challenges for government communication are: to communicate from a wider societal perspective, make the organization more communicative internally and (especially in the municipalities) do more work on citizen participation. Important competencies for communication officers are: analytical insight, empathy, advisory skills and knowledge of target groups. 
Vos, M. \& Westerhoudt, E. (2008), 'Trends in government communication in The Netherlands'. Journal of Communication Management, Volume 12, Issue 1, pp. 18-29.

Government communication has been emancipated and now shows a variety of communication practices. The various tiers of government organizations have different functions and need a different communication approach. There is, however, also a need for more coherence and coordination.

To the advisory board for this research (communication executives of ministries, provinces, waterboards and municipalities) it seemed obvious that government communication needs special attention in higher education. The topics mentioned by the respondents of this research clarify that programmes geared towards a company career do not enhance insight into how government organizations operate and how communication can contribute to the democratic functioning of public bodies. Educational programmes should show also how the various government tiers cooperate in their communication efforts.

The survey is conducted once every two years. The Government Communication Research Group hopes that it will facilitate a dialogue to further improve the quality of communication.

\section{References}

Katus, J. \& W. Volmer (2000), Government Communication in the Netherlands. Sdu, Den Haag.

Middel, R. (2004), Sprekend de bestuurder; eerste meting trendonderzoekoverheidscommunicatie, gehouden onder de ambtelijke, bestuurlijke en communicatieve top van Nederland, HU, Utrecht.

Vos, M., Setting the research agenda for governmental communication. Journal of Communication Management, Vol. 10 No. 3, 2006.

Vos, M. \& E. Westerhoudt (2006), Trendonderzoek overheidscommunicatie 2006; verschillen en overeenkomsten tussen de overheidssectoren, $\mathrm{HU}$, Utrecht (this publication includes the questionnaire).

\footnotetext{
About the authors

Marita Vos PhD is professor of Organizational Communication at the University of Jyväskylä, Finland. Previously she coordinated the Research Group Government Communication in Utrecht University of professional education. She studied Sociology with a major in Communication Studies and took her doctoral degree in the field of image policy. She has extensive experience in consultancy and higher education, and wrote several books about communication policy. She can be contacted at: marita.vos at jyu.fi.

Evelyn Westerhoudt B is a member of the Research Group Government Communication in Utrecht University of professional education, The Netherlands. She studied communication management and can be contacted at: evelyn.westerhoudt at hu.nl.
} 